\title{
Teachers' attitudes toward Personalized Learning Environments
}

\section{Atitudes dos professores em relação a ambientes de aprendizagem personalizados}

\author{
Lucila Pérez Cascante ${ }^{1}$, Manuel Cebrián ${ }^{2}$, Manuela Raposo ${ }^{3}$, Brenda Barrio ${ }^{4}$ \\ ${ }^{1}$ Universidad Casa Grande (UCG), Guayaquil, Equador. ORCID: https://orcid.org/0000-0003-3845-5329 \\ 2 Universidad de Málaga, Málaga, España. ORCID: https://orcid.org/0000-0002-0246-7398 \\ 2 Universidad de Vigo, Ourense, España. ORCID: https://orcid.org/0000-0001-7781-7818 \\ 2 Universidad de North Texas, Texas, United States. ORCID: https://orcid.org/0000-0001-5975-9159
}

Mail to/Autor para correspondência/Correo a: Lucila Pérez Cascante, Iperez@casagrande.edu.ec

Submitted/Recibido: 05 de janeiro de 2021; Approved/Aceptado: 12 de abril de 2021

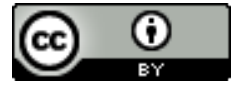

Copyright (C) 2021 Pérez, Cebrián, Raposo \& Barrio. All journal content (including directions, editorial policy and templates) is under a Creative Commons license Attribution 4.0 International. By being published by this journal, articles are free to use in educational, research and non commercial environments, with mandatory attribution of authorship. To further information check http://revistas.ufpr.br/atoz/about/submissions\#copyrightNotice.

\begin{abstract}
Introduction: teachers' attitude towards digital resources is a reliable predictor of how they will use technology in a pedagogical context. The purpose of this study was to identify the attitudes of teachers towards personalized learning environments (PLE) and factors that determine their acceptance or rejection to these new contexts. Method: the survey technique was applied to collect sample data using an instrument, which contains two scales, one to measure attitudes toward technology and the other to determine attitudes towards personalized learning environments, as well as a third section to collect participants demographic data. Results: outcomes of one-way ANOVAs of 334 teachers who were enrolled in the master's degree of education programs in Ecuador confirm that teachers have a positive attitude towards PLE, at a higher or lower level depending on their knowledge or use of PLE. Conclusions: inferences can be made that PLE can be an important pedagogical strategy as long as teachers' attitudes, experiences and knowledge are considered.
\end{abstract}

Keywords: Digital environments; Attitudes; Personal learning environments; PLE.

\begin{abstract}
Resumo
Introdução: a atitude dos professores em relação aos recursos digitais é um indicador confiável de como eles usarão a tecnologia em um contexto pedagógico. O objetivo deste estudo foi identificar as atitudes dos professores em relação aos ambientes de aprendizagem personalizados (PLE) e os fatores que determinam a sua aceitação ou rejeição a estes novos contextos. Método: a técnica de pesquisa foi aplicada para coletar dados amostrais por meio de um instrumento que contém duas escalas, uma para medir atitudes em relação à tecnologia e outra para determinar atitudes em relação a ambientes de aprendizagem personalizados, além de uma terceira seção para coletar dados demográficos dos participantes. Resultados: os resultados de ANOVAs unilaterais de 334 professores matriculados em programas de mestrado em educação no Equador confirmam que os professores têm uma atitude positiva em relação ao PLE, em um nível superior ou inferior, dependendo de seu conhecimento ou uso do PLE. Conclusões: pode-se inferir que o PLE pode ser uma estratégia pedagógica importante, desde que sejam consideradas as atitudes, experiências e conhecimentos dos professores.
\end{abstract}

Palavras-chave: Ambientes digitais; Atitudes; Ambientes de aprendizagem pessoal; PLE.

\section{INTRODUCTION}

The personalization of learning has always been a goal and has been identified as being a quality of teaching. Now-a-day, this topic has been debated and studies within academic contexts, in which research has been conducted in order to learn about its potential benefits on all educational levels. Mostly, it has been explored as the traditional or standardized educational model of a post-industrial era does not allow for focusing on the individualized learning of each student (Adams et al., 2017; Organización para la Cooperación y el Desarrollo Económico, 2006). The integration of information technology and communication (also known as TIC) in the learning processes, facilitate the personalization of pedagogical strategies and educational resources depending on the student's individual formal or informal learning needs. Specifically, the TICs open up spaces that are flexible for teaching to be more personalized for each student (Bustos, Engel, Saz, \& Coll, 2012; Dabbagh \& Fake, 2017).

The inception of personalized learning responds to a constructivist paradigm that considers learning to be an active and flexible process that is student-centered. This paradigm states that students are responsible for the construction of new knowledge based on meaningful learning experiences, that without being too complex, it could represent a challenge for the student that in turn, motivates their participation (Baker, 2016b). Also, it is grounded in the conectivist theory that is also centered in the student's learning process that is developed through its web of interactions and digital communities that are guided through diverse environments that are supported by technology (Downes, 2007). 
The creation of new learning scenarios that integrate both personalized components as and systematic ones, at the same time as new technologies and innovative pedagogical models are used, provide a great challenge for educational institutions. This is especially true when taking into consideration individual characteristics that play a role in the learning process (Dabbagh \& Fake, 2016), which means that the personalization of learning related to digital environments should guarantee not only the availability of resources and learning experiences, but also student and teacher participation in these spaces with a positive attitude toward this this pedagogical strategy, in order to have a positive effect in the students' learning (Sahin \& Kilsa, 2016a; Tur \& Marín, 2015).

Researchers from various disciplines have focused on the exploration of attitudes, taking into consideration its relationship with human behavior due to exposure to multiple stimuli (Myers, 2005). Specifically, it has generated multiple research studies about students' and teachers' attitudes towards the use of technology as a medium of learning as well as the variables that guide these attitudes (Dabbagh \& Fake, 2017; Rana, 2012). Nonetheless, there are limited studies that are focusing specifically on the identification of teachers' and students' attitudes and perceptions on the use of personalized learning environments even after potential benefits in the pedagogical process have been identified as well as the relevance of favorable acceptance of these to its effective use within learning (Dabbagh \& Fake, 2017; Sahin \& Kilsa, 2016a; Tur \& Marín, 2015).

To further contribute to the literature, the purpose of this study was to determine teachers attitudes towards personalized learning in digital environments and the factors that guide the development of these attitudes.

\section{Personalized Learning}

The personalization of learning is a topic that continues to be debated and explored within the educational community, where multiple studies have been conducted to identify its potential benefits (Léris \& Sein-Echaluce, 2011; Minguillon, Mor, Santanach, \& Guardia, 2005; Phillips, 2016). This framework focuses on the need to attend to individual student needs as an inclusive pedagogical strategy that facilitates the development of knowledge and skills (Baker, 2016a).

Personalized learning should consider the student's knowledge level and its complexity that implies that each learning experience should be adjusted depending on the student's needs. Bloom's Taxonomy is a valuable tool to support the development of personalized experiences that are focused on the student's needs since it allows the creation of learning objectives with specialized context that is better organized and includes flexible learning (Doyle \& Senske, 2016). The revised version of Bloom's Taxonomy for the Digital Era shows that there are six levels of complexity of the cognitive process: remember, understand, apply, analyze, evaluate, and create. Considering that these levels could help design instructional activities and evaluation that support accomplish learning goals and respond to the specific student needs depending on their cognitive development (Sideeg, 2016; Villalonga \& Marta-Lazo, 2015).

The personalization of pedagogical strategies and content based on students' needs is what defines personalized learning as a new and innovative learning model (Léris \& Sein-Echaluce, 2011). It is necessary to highlight that the personalization of learning is not the same as its individualization, although it focuses on the specific needs of each student (Banyard \& Underwood, n.d.). Personalized learning is a strategy that is contrary to a standardized pedagogical model that is rigid and based on the curriculum with restriction to space and time and that it could be the same for all students (Phillips, 2016). Therefore, a plan of study should include an adequate combination of diverse teaching methods that include autonomous learning within a group and community within a physical or virtual space (Baker, 2016a).

Similarly, in order to strengthen personalized learning, studies within educational contexts in diverse levels of learning show the importance of appropriate technological resources that allow for all students to engage in flexible and adaptable environments based on their needs (Adams et al., 2017; Léris \& Sein-Echaluce, 2011; Minguillon et al., 2005). Although there is still a prevalence of standardized digital systems, there is a market for the increase of the number of digital applications and environments focused on the personalization of learning within differentiated content or alternative pedagogical strategies (Baker, 2016b).

\section{Technology for Personalized Learning}

Technological resources have been a new alternative way to integrate many learning spaces that facilitate the personalization of the teaching and learning process, empowering the student in their development and leaving behind the teachers role of supervisor and assistant (Adams et al., 2017; Christensen, Horn, \& Johnson, 2011; Phillips, 2016). Gallego-Arrufat and Chaves-Barboza (2014) conducted a study with 375 participants in which they analyzed the tendencies of their work related to PLE, pointing out that this is a new concept that demands a higher number of empirical research studies.

There is an important number of experiences and investigations that have been conducted about personalized learning with the support of digital resources, such as using digital platforms like Learning Management Systems (LMS), as well as learning tools or applications that combine multimedia and social media tools (Minguillon 
et al., 2005). Through these experiences, students participate in learning activities with more autonomy and freedom where they can make decisions about content, timing, pacing, and place. Also, they can express their ideas and create content that is relevant to them or their peers (Baker, 2016b). The results of this research are often positive and show the potential benefits of personalized learning within digital contexts, although there is still a debate of its definition and efficacy. To alleviate some of these debates, researchers recommend expanding empirical research studies within higher education (Adams et al., 2017; Phillips, 2016).

Additionally, other studies highlight that current technological resources, used through various digital tools and social media, allow the teacher personalize learning by developing educational experiences centered in the student and their specific learning needs (Scherer \& Ferrari, 2018; Villalonga \& Marta-Lazo, 2015). From a technological perspective, the virtual environment was all the necessary digital resources and tools to support students' academic work could converge, has been named Personalized Learning Environment (PLE). In this space, students could complete activities guided for informal or formal learning, in collaboration in pairs or within larger learning communities (García \& González, 2017; Scherer \& Ferrari, 2018; V. \& Barroso, 2020).

There has been a significant amount of research studies about PLE within different contexts with theoretical and empirical foci that include its definition, origin, evolution, pedagogical and technological implications, supportive tools, instruction designs, and more (Castañeda, Tur, \& Torres-Kompen, 2019; Gallego-Arrufat \& Chaves-Barboza, 2014; R., Edirisingha, Canaleta, Alsinaa, \& Monguet, 2019; Tomé-Fernández, Curiel-Marín, \& Caraballo, 2020). These studies have identified multiple benefits of the use of learning technologies especially within PLE as it is student-centered and because of its pedagogical strategies that support their functioning (Bustos et al., 2012; García \& González, 2017; Scherer \& Ferrari, 2018; V. \& Barroso, 2020). However, the inclusion of technological resources is very limited within educational contexts, and in some cases, they do not show positive results. Some factors that have been identified as barriers that limit the inclusion of technology within learning environments has been teachers' attitudes towards this didactic resource (Al-Emran, Elsherif, \& Shaalan, 2016; López \& Ortega, 2017; Mejía, Silva, Villarreal, Suárez, \& Villamizar, 2018; Rana, 2012; Seraji, Ziabarin, \& Rokni, 2012).

\section{Attitudes toward Personalized Learning}

There are several definitions about attitudes, while they all agree in showing that they are a type of behavior that manifests a positive or negative reaction towards a specific thing or a situation (Myers, 2005). In the Multidimensional model, attitudes are determined by constructs that are integrated into three components: affective, cognitive, and behavioral, and generate responses within these components' functions. The first component connects emotions and feelings that determine the level of acceptance. The second component is linked to the information that is known about the object or the subject in the analysis. The third and final component determines de behavior that assumes a response to this object or subject (Álvarez et al., 2011; Cai, Fan, \& Du, 2017). Therefore, some researchers agree that attitudes are essential elements that allow the prediction of a person's possible behavior under specific conditions (Al-Emran et al., 2016; Rana, 2012).

However, to predict people's behaviors, it is imperative to consider that these are not constant and can be modified in relation to other factors, such as age, gender, individual experiences, family experiences, work experiences, and group experiences among others. Most importantly and based on the research, attitudes that are based on direct experiences are the best predictors of possible behaviors than attitudes based on secondary evidence (Álvarez et al., 2011; Cai et al., 2017). This implies that within a social, cultural, and job contexts, as well as people whom they interact with, could have important influence that could affect an individual's attitudes in positive or negative ways.

The population studied focused on teachers from diverse teaching levels (e.g., elementary, secondary, etc.) and diverse content areas (e.g., mathematics, science, etc.). In general, findings show that teachers have positive attitudes toward the use of new learning technologies and that these could change the function of targeted variables depending on the person and/or the context (Al-Emran et al., 2016; Álvarez et al., 2011; Al-Zaidiyeen, Lai Mei, \& Fook, 2010; Cavas, Cavas, Karaoglon, \& Kisla, 2009; Dartt, 2011; Males, 2011; Rana, 2012; Samak, 2006; Seraji et al., 2012).

Some studies, has determined that age (Males, 2011; Rana, 2012; Seraji et al., 2017), teaching experience (Males, 2011), and gender (Cavas et al., 2009; Males, 2011; Rana, 2012) do not influence teachers' attitudes To the contrary, other researchers have reported that age (Cavas et al., 2009; Samak, 2006), and teaching experience (Al-Emran et al., 2016; Samak, 2006; Seraji et al., 2012) does influence teachers' attitudes toward PLE. Variables such as knowledge and use of TICS have been found to show differences depending on teachers' attitudes towards these resources (Al-Zaidiyeen et al., 2010; Dartt, 2011).

In general, this has been used as the main focus of teacher preparation with the primary goal to understand their attitudes toward PLE and assure its effectiveness as a pedagogical strategy (Sahin \& Kilsa, 2016a). It has also been used to predict the integration of new learning environments for pre-service teachers (Tur \& Marín, 2015). With Sahin and Kilsa (2016a) study focusing on pre-service teachers in the areas such as Curriculum 
and Instruction to determine their attitudes toward PLE. Some of the variables that were studied were age, gender, knowledge about PLE, experiences in the use of PLE, and willingness to use PLE. The results show that there were significant differences between pre-service teachers' attitudes toward PLE depending on the variables discussed above.

Similarly, Tur and Marín (2015) focused on exploring this research question with pre-service teachers in early childhood education (undergraduate) and students in a master's degree program focused on secondary education. Their goal was to identify participants attitudes towards educational technology as future teachers and towards their learning experience and process in building an e-Portfolio. The results of the study show that participants had a positive attitude towards the use of learning technologies and e-Portfolios once they had used technological tools and had participated in building an e-Portfolio for their learning gains. Moreover, the researchers show that pre-service teachers developed positive expectations towards the integration of technology as part of their future teaching activities.

\section{Purpose of the Study}

Teachers' predisposition of the inclusion of technological tools in the learning development process with a combined attitude towards the use of these resources are an important and influential factor. This factor has been grounded in research findings from the literature review in our current study, which shows, that teachers with more positive attitudes have a better likelihood to include technological tools in their teaching practices than those with negative attitudes. Therefore, the purpose of this study is to explore the following research questions:

a) What are teachers' attitudes towards Personalized Learning?

b) What are the factors that influence these attitudes?

\section{METHODOLOGY AND RESULTS}

The sample of this study is focused on in-service teachers enrolled in a master's degree at a private university in a large city in Ecuador. A total of 334 teachers from two different cohorts participated in this study. A convenience sampling was employed to select the participants during years 1 and 3 in four different master's degree programs. Participants of this study were in-service teachers enrolled in various master's degree programs. A total of $35.3 \%$ of them were enrolled in the Educational Technology program, 29.3\% in Early Childhood, $17.7 \%$ in Inclusive Education (i.e., Special Education), and 17.7\% in English as a Second Language (Table 1).

\begin{tabular}{lcc}
\hline Maters Programs & $\mathrm{N}$ & $\%$ \\
\hline \multicolumn{1}{c}{ Total } & 334 & 100 \\
Educational Technology & 118 & 35,3 \\
Early Childhood Development & 98 & 29,3 \\
Inclusive Education & 59 & 17,7 \\
English as a Second Language & 59 & 17,7 \\
\hline
\end{tabular}

Table 1. Enrollment of participants by program.

Fonte: Graduate School archive.

The structure of the group based on gender included $68 \%$ female and $32 \%$ male. Grouping by age was composed of $43.4 \%$ of the sample is between 31 and 40 years old, $39.2 \%$ between 21 and 30 years old, and $17.4 \%$ over the age of 40 . Also, teachers with 1 to 5 years of experience represented $38.9 \%$ of the total sample, compared with $27.5 \%$ having between 6 to 10 years, and $23.6 \%$ having 10 or more years of teaching experience. The remaining $10 \%$ of the teacher sample had less than a one-year teaching experience (Table 2). 


\begin{tabular}{lcc}
\hline Description & $\mathrm{N}$ & $\%$ \\
\hline Gender & & \\
$\quad$ Female & 227 & 68,0 \\
$\quad$ Male & 107 & 32,0 \\
Age $\quad$ & & \\
21 to 30 years & 131 & 39,2 \\
31 a 40 years & 145 & 43,4 \\
More than 40 years & 58 & 17,4 \\
Teaching Experience & & \\
Less than 1 year & 31 & 9,3 \\
1 to 5 years & 130 & 38,9 \\
6 to 10 years & 92 & 27,5 \\
11 to 15 years & 45 & 13,5 \\
16 to 20 years & 21 & 6,3 \\
More than 20 years & 15 & 4,5 \\
\hline
\end{tabular}

Table 2. Demographic data of the sample. Fonte: Graduate School archive.

All programs use a virtual learning environment and the use of an introductory workshop (12 hours) on how to navigate online learning. The only program that includes great use of technology, as well as a course specific to the use of PLE, was the master's degree in Educational Technology.

\section{Measures}

An online survey was used to collect the data for this study. The survey included four sections: a) demographic information, b) knowledge and use of technology as means to learning, c) Attitudes Toward Technology Scale (Males, 2011), and d) Attitudes Toward PLE Scale (Sahin \& Kilsa, 2016b). Chronbach's alpha for the Attitudes Toward Technology scale and the Attitudes Toward PLE scale were in the excellent range with $\alpha=0.92$ and $\alpha=$ 0.95 respectively. Both scales have been validated through previous research studies for validity and internal consistency (Males, 2011; Sahin \& Kilsa, 2016a). Both instruments used a 5-point Likert scale that shows values from 1 to 5 (Table 3).

\begin{tabular}{|c|c|c|c|}
\hline Section & Itens & Response Options & Source \\
\hline a) Demographic data & 7 & Multiple choice & \\
\hline $\begin{array}{l}\text { b) PLE knowledge and experience, } \\
\text { and wellness to use it }\end{array}$ & 3 & $\begin{array}{l}\text { Not at all (1), Very little (2), } \\
\text { Fairly well (3), Quite well (4), } \\
\text { Very well (5) }\end{array}$ & $\begin{array}{l}\text { Adapted from } \\
\text { Sahin and Kilsa (2016a) }\end{array}$ \\
\hline $\begin{array}{l}\text { c) Attitudes toward technology } \\
\text { scale }\end{array}$ & 20 & $\begin{array}{l}\text { Totally disagree (1), Disagree (2), } \\
\text { Undecided (3), Agree (4), } \\
\text { Totally agree (5) }\end{array}$ & $\begin{array}{l}\text { Adapted from } \\
\text { Males (2011) }\end{array}$ \\
\hline d) Attitudes toward PLE scale & 22 & $\begin{array}{l}\text { Totally disagree (1), Disagree (2), } \\
\text { Undecided (3), Agree (4), } \\
\text { Strongly agree (5) }\end{array}$ & $\begin{array}{l}\text { Adapted from } \\
\text { Sahin and Kilsa (2016a) }\end{array}$ \\
\hline
\end{tabular}

Table 3. Structure of the survey questionnaire.

Fonte: Graduate School archive.

\section{Data Collection}

The online survey was employed using Google Forms for students to have flexibility and anonymity. Data were collected during class time while the students learned in a computer lab. Before the start of the survey, participants were given an explanation of the objective and goal of this study as well as directions to answering the questions in the survey. Each student took between 30 and 40 minutes to respond to the survey. All students were given the opportunity to opt-out of the survey if they wished and did not have any repercussion to not participating in the study.

\section{Data Analysis}

To best explore the research questions, descriptive statistics and one-way analyses of variance (one-way ANOVA) were employed. These statistical analyses were selected to establish how the means of variables differed from one group to another (Hittleman \& Simon, 2006). The dependent variable was focused on the "teachers' attitudes" and was evaluated for the test of normality and homoscedasticity as prescribed by the use of ANOVAs. 


\section{Teachers' Attitudes toward PLE}

Results of the variable "Teachers' Attitudes" had a normal distribution with a Skewness of -0.242 and Kurtosis of -0.76 , which values show in the normal distribution range between +1 and -1 . A mean average was equal to 4.328 with a range between 3.22 and 5 . This means that the majority of the teachers had a positive attitude towards personalized learning due to the mean being closer to the maximum value of the scale.

Descriptive statistics show that the majority of answers were concentrated within levels of Agree and Totally Agree, which represents $98.5 \%$ of the sample. The $1.5 \%$ remaining matched the Neutral level within the scale. As previously discussed, these results show that teachers that include the objective of the group, in general, have a positive attitude towards personalized learning environments.

\section{Influencing Factors of Teachers' Attitudes toward PLE}

The results of the Kolmorogov-Smirnov test $(\mathrm{p}=0.000)$ applied to the dependent variable Teachers' Attitudes towards PLE indicate that there is a normal distribution. Statistically significant differences between groups were observed in the one-way ANOVA depending on age $(\mathrm{F}(2,331)=1.861, \mathrm{p}=0.157)$, gender $(\mathrm{F}(1,332)=$ 1.103, $\mathrm{p}=0.293)$, teaching experience in years $(\mathrm{F}(5,328)=1.034, \mathrm{p}=0.399)$, knowledge of $\mathrm{PLE}(\mathrm{F}(4,329)=$ 1.736, $\mathrm{p}=0.142)$, desire to use $\operatorname{PLE}(\mathrm{F}(3,330)=0.415, \mathrm{p}=0.743)$, and program enrolled $(\mathrm{F}(3,330)=0.986$, $\mathrm{p}=0.034)$.

Although the factor of experience with $\operatorname{PLE}(\mathrm{F}(3,330)=2.920, \mathrm{p}=0.034)$, as well as attitudes toward TICs ( $\mathrm{F}(2$, $331)=3.425, \mathrm{p}=0.034$ ), had a $\mathrm{p}$-value lower than 0.05 , it should be considered as a non-significant difference. It is possible that the differences observed were due to large or small groups (Hittleman \& Simon, 2006).

To determine which factors could influence teachers' attitudes, a one-way Analysis of Variance (ANOVA) was conducted to compare mean scores of teachers' attitudes within groups in relation to the independent variables. To interpret the results, a statistical significance was set at $\mathrm{p}>0.05$. Results of this study show that age and gender did not yield statistically significant results $(\mathrm{p}>0.05)$ when compared as groups for teachers' attitudes toward PLE. This means that all teachers' had similar attitudes toward PLE. Similarly, teacher's experience did not yield any significant differences toward teacher's attitudes. In other words, teacher's attitudes did not vary in a significant way due to their years of teaching experience.

The ANOVA results for knowledge about PLE $(\mathrm{F}(4,329)=13.029, \mathrm{p}=0.000)$, experience with $\mathrm{PLE}(\mathrm{F}(3,330)$ $=10.749, \mathrm{p}=0.000)$, and desire to use $\operatorname{PLE}(\mathrm{F}(3,330)=11.28, \mathrm{p}=0.000)$, show that they influence teacher's attitudes $(\mathrm{p}<0.05)$. These results show that there are statistically significant differences between groups that include each variable as it relates to attitudes toward PLE.

In-between group comparison of the enrolled program variable included a statistically significant result with $\mathrm{p}=0.008$, although the $\mathrm{F}=3.985$ was larger than the Fcrit $=3.88$. These results show that although the means between groups differ, the differences are not significant. The means of master's in Educational Technology and English as a Second Language programs were the highest. These differences could be related to how each program of study is developed for each program, which then determines the profile of each student.

Teacher's attitudes toward PLE were affected by the use of technology as a didactic strategy. ANOVA results show that the $\mathrm{F}=71.654$ is larger than the Fcrit $=4.71$, which show statistically significant results between mean group attitudes toward PLE $(\mathrm{p}=0.000)$.

To answer the second research question, the results of this study show that teacher's attitudes toward PLE are not different due to teachers' age, gender, or years of teaching experience. Contrary to these results, the other five factors analyzed show statistically significant differences between groups as they relate to teacher's attitudes toward PLE. In other words, knowledge about PLE, experience with PLE, wanting to use PLE, master's program, and attitudes toward technology impact teacher's attitudes toward PLE.

\section{CONCLUSIONS AND FUTURE DEVELOPMENTS}

Personalized learning has been a continuous concern by teachers as well as researchers from various perspectives (Baker, 2016a; Sideeg, 2016; Villalonga \& Marta-Lazo, 2015). As an answer to this worry, there have been new technological tools that have been facilitated personalized learning. Recently, this has become a potential in the construction of new digital flexible and open spaces, like personalized learning environments, that allows using student-centered educational strategies. In contradistinction, teacher's attitudes toward emerging technologies have been seen as potential barriers that limit their integration within learning environments.

The PLE, in its unique condition, differs depending on the participant's characteristics, and their level of knowledge, skills, motivation, etc. Specifically, they are configured according to their learning experiences, both formal and informal (Cebrián-de-la Serna, Bartolomé-Pina, Cebrián-Robles, \& Ruiz-Torres, 2015), non-formal and self-taught (Peña, 2013). Thus, educational institutions in their role as educators and generators of knowledge, 
rather than producers, transmitters and disseminators of knowledge, cannot ignore the role of technology and digital environments in the integral development of people. This is particularly relevant in the development of teachers, since they in turn act as disseminators, responsible for the education of children, youth, and adults.

Moreover, the integration of PLE in the classroom implies addressing methodological and pedagogical changes since the focus of attention is on the students and their learning, and not so much on the content. The teacher modifies her role to facilitate, guide, and mediate this process, suggesting the student digital tools that allow them to access new sources of knowledge and strengthen their ability to learn. It is evident that this requires a deep and varied didactic and technological training, or even a transformation of educational practices, so that the development and attitude of teachers become the cornerstone of the process. For this, the current study focused on two objectives: a) determining teachers' in a master's program's attitudes toward personalized learning environments, and b) explore factors that influence these attitudes.

Results focusing on the first research question show that, in general, teachers' attitudes toward the use of learning technologies in personalized learning are positive. These results confirm those from other studies conducted about the use of learning technologies in diverse contexts (Al-Emran et al., 2016; Álvarez et al., 2011; Al-Zaidiyeen et al., 2010; Cavas et al., 2009; Males, 2011; Rana, 2012; Samak, 2006; Seraji et al., 2012), as well as those focusing on attitudes towards personalized learning environments (Sahin \& Kilsa, 2016a; Tur \& Marín, 2015).

Answers to the second research question show that the factors that influence teachers' attitudes are knowledge about PLE, experiences with using PLE, willingness to use PLE, master's program enrolled, and attitudes towards technology. In contrast, factors that do not show to influence teachers' attitudes are age, gender, and teaching experience (number of years). In contrast, factors that influence teachers' attitudes are knowledge about PLE, experiences using PLE, willingness to use PLE, master's program enrollment, and attitudes towards technology.

Results showing that age is not an influential factor in teachers' attitudes toward PLE align with the findings from Males (2011), Rana (2012), and Seraji et al. (2017) but are contrary to those shown by Cavas et al. (2009) and Samak (2006). It is possible that these differences are related to other variables within the sociocultural context where the studies have been conducted, as well as being determined by other factors based on experience, expectations, training, and prior knowledge of what these technologies are for or can be used for. Similarly, researchers have confirmed that gender is also not a factor that creates significant differences in teachers' attitudes toward technology as an educational resource (Cavas et al., 2009; Males, 2011; Rana, 2012). In initial teacher education contexts, gender, such as grade level, does not have an effect on the perception and use of PLEs (Şahin \& Uluyol, 2016).

Contrary to what some studies have found regarding the teachers' years of teaching experience factor as influencing their attitudes (Al-Emran et al., 2016; Samak, 2006; Seraji et al., 2012), the results of the current study shows that teachers' experiences do not play a significant role in their attitudes toward technology (Males, 2011). The differences between the results of these studies could be the accessibility of technology as well as its use to guide learning processes within educational environments.

Various studies have determined that factors related to knowledge and experiences on the use of technological resources in learning, specifically within PLE, are an influential factor in teachers' attitudes towards those resources (Álvarez et al., 2011; Al-Zaidiyeen et al., 2010; Cai et al., 2017; Sahin \& Kilsa, 2016a; Tur \& Marín, 2015). Similar to these results, the current study highlights that these factors do show a difference in teachers' attitudes towards the integration of technology as an educational resource in educational settings.

In connection with the type of master's program factor, the results show that this factor generates significant differences in teachers' attitudes towards technology and PLE. These results are similar to those in Sahin and Kilsa (2016a) study, where they show that students attitudes toward PLE could be affected by their area or program of study. A plausible explanation of these differences could be the content within the program of study in each one of the master's degree programs, which include a larger or lesser number of courses related to learning technologies. For example, in the Learning Technology master's degree program, where the participants show a greater level of positive attitude towards PLE in comparison to those in all other master's degree program participants in this study. Future research should focus on these differences.

Personalized Learning Environments are a pedagogical strategy that involves the use of technology to create digital environments that facilitate personalized learning carried out by the teacher for the student. In other words, PLE establishes a specific way to use technological resources within educational contexts. It is imperative to point out that the use of PLE is a more advanced level of application that requires greater knowledge of specific digital tools. For this reason, the current study focused on determining teachers' attitudes toward technology and compare them with their attitudes toward PLE. The results show that both variables are related, which support findings from Al-Emran et al. (2016), Rana (2012), and Seraji et al. (2012), which discuss that teachers' attitudes toward technology influence their decision to use this educational tool within the classroom.

Knowing teachers' attitudes in their preparation towards the use of technology and PLE is crucial as it allows 
them to show their disposition towards integrating these new resources in their teaching. That is, if the teachers in their role of life-long learner develop a positive attitude toward PLE, it could be assumed that these experiences could be replicated within their teaching practice. Therefore, to assure the successful integration of digital resources in learning environments, it is imperative to prepare teachers in their use of technology and integration within pedagogical experiences, that will then stimulate the development of positive attitudes towards them.

Researchers and practitioners should continue to take into consideration teaches' attitudes as they explore the impact of innovative pedagogical changes such as the use of PLE. Studies focused on the various ways that PLE is implemented within educational contexts should be considered, not only in the United States but across the world. The current study, as a start, includes teachers from Ecuador as they implement this pedagogical strategy. Using frameworks such as the Concerns Based Adoption Model (Hall \& Hord, 2006) could provide a framework to better understand these changes within the classroom.

The CBAM has been used in the past few decades to identify teachers' concerns, perspectives, and attitudes toward the use of innovative educational practices such as the use of computer-based learning (Bresnitz, Ross, Hall, \& Stiegelbauer, 2007), pre-referral models for students with disabilities (Gallego-Arrufat \& Chaves-Barboza, 2014), and technology education (Yuliang \& Huang, 2005). In research and practice, implications on using frameworks such as the CBAM, could not only help further explore the PLE phenomenon as it is implemented, but it could also shape future professional development based on specific teachers' needs. Most importantly, if teachers' personal experiences are affected by a specific change (e.g., implementation of PLE), it is imperative to understand and observe these experiences in order for the change to be sustained as an educational model (Hall \& Hord, 2006). 


\section{REFERENCES}

Adams, S., Cummins, M., Davis, A., Freeman, A., Hall, C., \& Ananthanarayanan, V. (2017). Nmc horizon report: 2017 higher education edition. Austin, Texas: The New Media Consortium. Retrieved from https://files.eric.ed.gov/ fulltext/ED582134.pdf

Al-Emran, M., Elsherif, H., \& Shaalan, K. (2016). Investigating attitudes towards the use of mobile learning in higher education. Computers in Human Behavior, 56, 93-106. doi: 10.1016/j.chb.2015.11.033

Álvarez, S., Cuellar, C., López, B., Adrada, C., Anguiano, R., Bueno, A., ... Gómez, S. (2011). Teacher's attitudes towards educational technology in english language institutes. Edutec-e Revista Electrónica de Tecnología Educativa, 35. Retrieved from http://edutec.rediris.es/Revelec2/ Revelec35/

Al-Zaidiyeen, N., Lai Mei, L., \& Fook, F. (2010). Teachers' attitudes and levels of technology use in classrooms: The case of jordan schools. International Education Studies, 3(2), 211-218. doi: 10.5539/ies.v3n2p211

Baker, R. (2016a). Competencies and personalized learning. In M. murphy, s. redding, j. twyman (eds.), handbook on personalized learning for states, districts, and schools (pp. 318). Temple University, Center on Innovations in Learning: Philadelphia.

Baker, R. (2016b). Using learning analytics in personalized learning. In M. murphy, s. redding and j. twyman (eds.). handbook on personalized learning for states, districts, and schools (pp. 165-174). Temple University: Philadelphia.

Banyard, P., \& Underwood, J. (n.d.). Understanding the learning space. eLearning Papers, 9.

Bresnitz, E. A., Ross, M., Hall, G., \& Stiegelbauer, S. (2007). A randomized study to assess the facilitation of faculty implementation of computer-based learning in medical education. Journal of Medical Education Technologies, 6(3), 19-35.

Bustos, A., Engel, A., Saz, A., \& Coll, C. (2012). Integrating personal and institutional learning environments. Retrieved from http://www.academia.edu/ 5757502/Integrating_personal_and_institutional_virtual _learning_environments

Cai, Z., Fan, X., \& Du, J. (2017). Gender and attitudes toward technology use: a meta-analysis. Computers and Education, 105, 1-13. doi: 10.1016/j.compedu.2016.11.003

Castañeda, L., Tur, G., \& Torres-Kompen, R. (2019). Impacto del concepto ple en la literatura sobre educación: la última década. Revista Iberoamericana de Educación a Distancia, 22(1), pre-print. doi: 10.5944/ried.22.1.22079

Cavas, B., Cavas, P., Karaoglon, B., \& Kisla, T. (2009). A study on science teachers' attitudes toward information and communication technologies in education. The Turkish Online Journal of Educational Technologies, 8(2), 20-32.

Cebrián-de-la Serna, M., Bartolomé-Pina, A., CebriánRobles, D., \& Ruiz-Torres, M. (2015). Estudio de los portafolios en el practicum: análisis de un ple-portafolios. RELIEVE, 21(2), art M1. doi: 10.7203/relieve.21.2.7479

Christensen, C., Horn, M., \& Johnson, C. (2011). Disrupting class: How disruptive innovation will change the way the world learns. New York: McGraw-Hill.

Dabbagh, N., \& Fake, H. (2016). La investigación ante los desafíos de los escenarios de aprendizaje futuros. Revista de Educación a Distancia, 50, 1-24. doi: 10.6018/red/50/13
Dabbagh, N., \& Fake, H. (2017). College students perceptions of personal learning environments through the lens of digital tools, processes and spaces. Journal of New Approaches in Educational Research, 6(1), 30-38. doi: 10.7821/naer.2017.1.215

Dartt, M. (2011). The impact of teachers' attitudes on technology use during instruction (Doctoral dissertation, Liberty University, Virginia, United States). Retrieved from http://digitalcommons.liberty.edu/cgi/viewcontent.cgi ?article $=1466 \&$ context=doctoral $\quad$ (Tese de doutorado)

Downes, S. (2007). Learning networks in practice. Montreal, Canada: National Research Council Publications Records. Retrieved from https://www.academia.edu/ 2869500/Learning_networks_in_practice

Doyle, S., \& Senske, N. (2016). Exploring learning objectives for digital design in architectural education. In 86 architecture conference proceedings and presentations. Retrieved from http://lib.dr.iastate.edu/arch_conf/86

Gallego-Arrufat, M. J., \& Chaves-Barboza, E. (2014). Tendencias en estudios sobre entornos personales de aprendizaje (ple). Revista Electrónica de Tecnología Educativa, 49. Retrieved from http://edutec.rediris.es/Revelec2/Revelec49/ n49 Gallego Chaves.html

García, J., \& González, M. (2017). Entornos personales de aprendizaje de estudiantes universitarios costarricenses de educación: análisis de las herramientas de búsqueda de información. Revista de Investigación Educativa, 35(2), 389-407. doi: 10.6018/rie.35.2.253101

Hall, G. E., \& Hord, S. M. (2006). Implementing change: Patterns, principles, and potholes. Boston: Ally \& Bacon.

Hittleman, D., \& Simon, A. (2006). Interpreting educational research: An introduction for consumers of research. New York: Pearson.

Léris, D., \& Sein-Echaluce, M. (2011). La personalización del aprendizaje: Un objetivo del paradigma educativo centrado en el aprendizaje. ARBOR, 187(3), 123-134. doi: 10.3989/arbor.2011.Extra-3n3135

López, J., \& Ortega, J. (2017). Cambios en la percepción del profesorado sobre la incidencia positiva de las tecnologías digitales en educación primaria y secundaria. Revista Electrónica de Investigación y Docencia, 18, 97-108. doi: 10.17561/reid.v0i18.3401

Males, N. (2011). Uses and attitudes toward educational technology among new teachers in urban schools: a correlacional study (Doctoral dissertation, University of Phoenix, Texas, United States). Retrieved from https://pqdtopen .proquest.com/doc/883382579.html?FMT=AI (Tese de doutorado)

Mejía, A., Silva, C., Villarreal, C., Suárez, D., \& Villamizar, C. (2018). Estudio de los factores de resistencia al cambio y actitud hacia el uso educativo de las tic por parte del personal docente. Revista Boletín Redipe, 7(2), 53-63. Retrieved from http://revista.redipe.org/index.php/1/article/ view $/ 428$

Minguillon, J., Mor, E., Santanach, F., \& Guardia, L. (2005). Personalización del proceso de aprendizaje usando learning objects reutilizables. Revista de Educación a Distancia, IV. Retrieved from http://www.um.es/ead/red/M4/ minguillon32.pdf

Myers, D. (2005). Psicología social. Mexico City: McGrawHill.

Organización para la Cooperación y el Desarrollo Económico. 
(2006). Escuelas del futuro: La personalización de la enseñanza. Retrieved from http://www.oecd.org/education/ school/36234148.pdf

Peña, I. (2013). El ple de investigación-docencia: el aprendizaje como enseñanza. In L. castañeda y j. adell (eds.), entornos personales de aprendizaje: Claves para el ecosistema educativo en red (pp. 93-110). Alcoy: Marfil.

Phillips, B. (2016). Beyond classroom learning: Personalized learning through digital technologies. Retrieved from http:// hdl.handle.net/20.500.11790/255

R., T., Edirisingha, P., Canaleta, X., Alsinaa, M., \& Monguet, J. (2019). Personal learning environments based on web 2.0 services in higher education. Telematics and Informatics, 38, 194-206. doi: 10.1016/j.tele.2018.10.003

Rana, H. (2012). A study to assess teacher educators' attitudes towards technology integration in classrooms. MIER Journal of Educational Studies, Trends \& Practices, 2(2), 190-205. Retrieved from http://mierjs.in/ojs/index.php/ mjestp/article/view/36

Sahin, M., \& Kilsa, T. (2016a). An analysis of university students attitudes towards personalized learning environments. The Turkish Online Journal of Educational Technology, 15(1), 1-10. Retrieved from https://files.eric.ed.gov/ fulltext/EJ1086195.pdf

Sahin, M., \& Kilsa, T. (2016b). Developing a valid and reliable attitude scale towards personalized learning. Kastamonu Education Journal, 24(4), 1713-1726. Retrieved from https://kefdergi.kastamonu.edu.tr/index.php/ Kefdergi/article/view/497

Samak, Z. (2006). An exploration of jordanian english language teachers 'attitudes, skills, and access as indicator of information and communication technology integration in jordan (Doctoral dissertation, Florida State University, Florida, United States). Retrieved from http://diginole.lib.fsu.edu/ islandora/object/fsu:168189/datastream/PDF/view (Tese de doutorado)

Scherer, P., \& Ferrari, D. (2018). Experiences with web 2.0 in school settings: a framework to foster educational practices based on a personal learning environment perspective. Educação em Revista, 34, 1-27. doi: 10.1590/0102-4698162010

Seraji, N., Ziabarin, R., \& Rokni, S. (2012). Teacher's attitudes towards educational technology in english language institutes. International Journal of English Linguistics, 7(2). doi: $10.5539 /$ ijel.v7n2p176

Sideeg, A. (2016). Bloom's taxonomy, backward design, and vygotsky's zone of proximal development in crafting learning outcomes. International Journal of Linguistics, $8(2)$. Retrieved from http://www.macrothink.org/journal/ index.php/ijl/article/view/9252

Tomé-Fernández, M., Curiel-Marín, E., \& Caraballo, E. (2020). Use of mobile technologies in personal learning environments of intercultural contexts: Individual and group tasks. Electronics, 9(5), 876. doi: 10.3390/electronics 9050876

Tur, G., \& Marín, V. (2015). Exploring students 'attitudes and beliefs towards e-portfolios and technology in education. Enseñanza and Teaching, 33(1), 57-82. doi: $10.14201 /$ et20153315782

V., J., \& Barroso, J. (2020). Identificación de los componentes del entorno personal de aprendizaje de estudiantes de ingeniería. EDMETIC, 9(2), 202-221. doi: 10.21071/edmetic.v9i2.12602
Villalonga, C., \& Marta-Lazo, C. (2015). Modelo de integración educomunicativa de apps móviles para la enseñanza y aprendizaje. Revista de Medios y Educación, 46. Retrieved from http://www.redalyc.org/pdf/368/36832959014.pdf

Yuliang, L., \& Huang, C. (2005). Concerns of teachers about technology integration in the usa. European Journal of Teacher Education, 28(1), 35-48.

Şahin, S., \& Uluyol, C. (2016). Preservice teachers perception and use of personal learning environments (ples). ). International Review of Research in Open and Distributed Learning, 17(2). doi: 10.19173/irrodl.v17i2.2284
How to cite this article (APA):

Pérez, L. C., Cebrián, M., Raposo, M., \& Barrio, B. (2021). Teachers' attitudes toward Personalized Learning Environments. AtoZ: novas práticas em informação e conhecimento, 10(2), 97 - 106. Retrieved from: http:// dx.doi.org/10.5380/atoz.v10i2.78774 